\title{
Pengaruh Jumlah Bibit dan Modifikasi Sistem Tanam Jajar Legowo Terhadap Pertumbuhan dan Produksi Padi Sawah (Oryza sativa L.) Di Desa Tanjung Mulia Kecamatan Tanjung Morawa Kabupaten Deli Serdang
}

The Effect of Seeds Number and Modified Jajar Legowo Planting System to The Growth and Yield for Rice (Oryza sativa L.) in Desa Tanjung Mulia Kecamatan Tanjung Morawa Kabupaten Deli Serdang

\author{
Elseloni Rotua Afnita Simangunsong , Erwin Masrul Harahap*, Alida Lubis \\ Program Studi Agroteknologi, Fakultas Pertanian, USU, Medan 20155 \\ *Corresponding author : ermashar@yahoo.com
}

\section{ABSTRACT}

The research was conducted at rice field in Desa Tanjung Mulia, Kecamatan Tanjung Mulia, Kabupaten Deli Serdang, start from May until September 2017 using completely randomized design with two factors, i.e the first factor number of seeds (1 seed, 2 seeds, 3 seeds) and the second factor the plant population based on modified jajar legowo planting system (conventional planting system with spacing $30 \mathrm{~cm} \times 30 \mathrm{~cm}$ population of 35 clump per plot, jajar legowo 4:1 planting system with spacing $20 \mathrm{~cm} \times 20 \mathrm{~cm}$ population of 60 clump per plot, jajar legowo planting system with spacing $10 \mathrm{~cm} \times 20 \mathrm{~cm}$ population of 114 clump per plot, jajar legowo planting system with spacing $30 \mathrm{~cm} \times 30 \mathrm{~cm}$ and plant inserted every $10 \mathrm{~cm}$ population of $154 \mathrm{clump}$ per plot, jajar legowo planting system with spacing $10 \mathrm{~cm} \times 10 \mathrm{~cm}$ population of $190 \mathrm{clump}$ per plot). The area of land used is $15915,2 \mathrm{~cm}$, with a total plot is 45 plots, each plot is $2 \mathrm{~cm} \times 1,5 \mathrm{~cm}$. The result showed that 1 seed of clump with jajar legowo planting system with population of 60 clump per plot significantly influence the increase of production. The interaction between number of seeds and plant population significantly increased plant height but did not significantly increase rice production (Oryza sativa L.).

Keywords : number of seeds, modification of jajar legowo planting system, rice

\section{ABSTRAK}

Penelitian dilaksanakan di lahan sawah Desa Tanjung Mulia, Kecamatan Tanjung Morawa, Kabupaten Deli Serdang, dimulai dari bulan Mei hingga September 2017 dengan menggunakan metode rancangan acak lengkap faktorial dengan 2 faktor, yaitu faktor pertama jumlah bibit (1 bibit, 2 bibit, 3 bibit) dan faktor kedua populasi tanaman berdasarkan modifikasi sistem tanam jajar legowo (sistem tanam konvensional dengan jarak tanam $30 \mathrm{~cm} \times 30 \mathrm{~cm}$ populasi 35 rumpun per plot, sistem tanam jajar legowo 4:1 dengan jarak tanam $20 \mathrm{~cm} \times 20 \mathrm{~cm}$ populasi 60 rumpun per plot, sistem tanam jajar legowo dengan jarak tanam $10 \mathrm{~cm}$ x $20 \mathrm{~cm}$ populasi 114 rumpun per plot, sistem tanam jajar legowo dengan jarak tanam $10 \mathrm{~cm}$ x $20 \mathrm{~cm}$ dan disisipi tanaman setiap $10 \mathrm{~cm}$ populasi 154 rumpun per plot, sistem tanam jajar legowo dengan jarak tanam $10 \mathrm{~cm} \times 10 \mathrm{~cm}$ populasi 190 rumpun per plot). Luas lahan yang digunakan sebesar $15915,2 \mathrm{~cm}$, dengan total plot sebanyak 45 plot, masing-masing plot berukuran $2 \mathrm{~cm} \times 1,5 \mathrm{~cm}$. Hasil penelitian menunjukkan bahwa penggunaan 1 bibit per rumpun dengan sistem tanam jajar legowo dengan jarak tanam $20 \mathrm{~cm} \times 20 \mathrm{~cm}$ populasi 60 rumpun per plot memberikan pengaruh nyata dalam peningkatan produksi padi sawah. Interaksi antara faktor jumlah bibit dan populasi tanaman secara nyata meningkatkan tinggi tanaman tetapi tidak meningkatkan produksi padi sawah (Oryza sativa L.).

Kata Kunci : jumlah bibit, modifikasi sistem tanam jajar legowo, padi sawah 


\section{PENDAHULUAN}

Hampir seluruh penduduk Indonesia memenuhi kebutuhan bahan pangan utamanya dari tanaman padi. Dengan demikian, tanaman padi merupakan tanaman pangan utama yang dapat mempengaruhi kehidupan masyarakat. Berdasarkan data dari Badan Pusat Statistik (2016), capaian produksi padi Indonesia pada tahun 2015 mencapai 75,40 juta ton gabah kering giling (GKG) yang mengalami kenaikan 4,55 juta ton dibandingkan tahun 2014, sedangkan produksi padi yang dicapai Provinsi Sumatera Utara pada tahun 2015 sebesar 4,04 juta ton gabah kering giling yang juga mengalami peningkatan dibandingkan tahun 2014. Produksi tersebut belum dapat memenuhi tingkat konsumsi beras masyarakat Indonesia per kapita, yaitu sebesar 97,56kg/kapita/tahun pada tahun 2016.

Menurut Karokaro et al. (2014) dalam upaya pencapaian target program peningkatan produksi beras nasional $(\mathrm{P} 2 \mathrm{BN})$ pemerintah dalam hal ini Departemen Pertanian melalui badan pengembangan dan penelitian telah banyak mengeluarkan rekomendasi untuk diaplikasikan oleh petani. Salah satu rekomendasi ini adalah penerapan sistem tanam yang benar dan baik melalui pengaturan jarak tanam yang dikenal dengan sistem tanam jajar legowo. Pada prinsipnya sistem tanam jajar legowo adalah meningkatkan populasi dengan cara mengatur jarak tanam. Sistem tanam ini juga memanipulasi tata letak tanaman, sehingga rumpun tanaman sebagian besar menjadi tanaman pinggir (Ikhwani et al. 2013).

Modifikasi jarak tanam pada cara tanam legowo bisa dilakukan dengan berbagai pertimbangan. Secara umum, jarak tanam yang dipakai adalah $20 \mathrm{~cm}$ dan bisa dimodifikasi menjadi $22,5 \mathrm{~cm}$ atau $25 \mathrm{~cm}$ sesuai pertimbangan varietas padi yang akan ditanam atau tingkat kesuburan tanahnya (Bobihoe, 2013).

Berdasarkan hasil penelitian Satria (2016) pada sistem tanam jajar legowo $4: 1(20 \mathrm{~cm} \times 10 \mathrm{~cm})$ menghasilkan jumlah anakan yang maksimum. Hal ini menunjukkan bahwa semakin rapat jarak tanam maka akan semakin banyak pula jumlah anakan yang dihasilkan sehingga produksi padi juga meningkat. Selain itu, jarak tanam yang rapat juga tidak berpengaruh nyata terhadap tinggi tanaman jika diberikan pupuk yang berimbang.

Menurut Nasution (2014) produksi yang tinggi tidak akan mungkin dapat dicapai bila tidak diiringi dengan dosis pupuk yang berimbang. Oleh karena itu, dalam menentukan dosis pupuk untuk mencapai target produksi dapat dilakukan dengan menganalisis unsur hara tanaman padi yang hilang akibat panenan (jerami dan gabah). Dengan demikian, kebutuhan hara yang diperlukan tanaman akan terpenuhi dan produksi yang dihasilkan akan maksimal.

Metode The System of Rice Intensification (SRI) merupakan salah satu metode intensifikasi yang dapat dilakukan agar kemampuan genetik tanaman dapat dikembangkan secara optimal. Budidaya dengan SRI telah mulai diterapkan di Indonesia untuk meningkatkan produktivitas, tetapi masih perlu dilakukan perbaikanperbaikan untuk mencapai hasil optimal. Penekanan pada inovasi teknologi metode SRI terletak pada pengelolaan pada sistem pengairan namun, keberhasilan budidaya tanaman khususnya tanaman padi banyak ditentukan oleh faktor lain antara lain jumlah bibit per lubang tanam. Budidaya padi dengan sistem SRI yang penanamannya menggunakan cara tanam tunggal dengan satu benih per lubang tanam, akan memudahkan tiap tanaman bisa menyerap nutrisi, oksigen, dan sinar matahari secara lebih optimal (Susilo et al. 2015; Ali et al. 2017).

Pada umumnya, petani menggunakan jumlah bibit 3-5 batang per lubang dan bahkan ada yang mencapai 6-12 bibit per lubang. Hal ini didasarkan kepada pemikiran bahwa semakin banyak bibit yang digunakan akan menghasilkan malai lebih banyak. Akan tetapi, penanaman lebih dari satu bibit per lubang tanam, dapat mengakibatkan persaingan antar tanaman dalam memperebutkan makanan dan sinar matahari, sehingga produksi yang dihasilkan tidak 
optimum. Oleh karena itu, digunakan model penanaman hanya 1 bibit dan maksimal 3 bibit umur muda dalam setiap lubangnya (tancap). Hal tersebut akan memungkinkan tanaman tumbuh dengan cepat dan mampu memproduksi anakan secara maksimal (Suswadi dan Imam, 2011).

Berdasarkan hasil penelitian Harahap (2013) rata-rata jumlah anakan dan berat netto gabah kering per lubang tanam didominasi oleh perlakuan 1 bibit per lubang tanam, meskipun hasilnya tidak berbeda nyata dengan perlakuan 2 dan 3 bibit per lubang tanam. Penanaman bibit dengan jumlah relatif banyak (5-10 batang/rumpun) menyebabkan terjadinya persaingan (kompetisi) sesama tanaman padi (Burbey et al. 2014).

Oleh karena itu, berdasarkan uraian tersebut, penulis tertarik untuk melakukan penelitian lebih lanjut mengenai pengaruh jumlah bibit per lubang tanam dan sistem tanam jajar legowo untuk memperoleh pertumbuhan dan produksi padi sawah yang maksimal. Dari hasil penelitian ini diharapkan petani dapat menerapkannya untuk meningkatkan hasil produksi padi.

\section{BAHAN DAN METODE}

Penelitian ini dilaksanakan di lahan sawah Desa Tanjung Mulia Kecamatan Tanjung Morawa Kabupaten Deli Serdang, dimulai dari bulan Mei sampai dengan September 2017.

Bahan-bahan yang digunakan dalam penelitian ini adalah benih padi varietas Inpari 32, cup air mineral, pupuk urea, SP-36, $\mathrm{KCl}$, dolomit, pestisida dan fungisida untuk mengendalikan hama dan penyakit. Alat-alat yang digunakan dalam penelitian ini adalah cangkul, pacak bambu, tali plastik, meteran, timbangan analitik, alat tulis, dan kamera.

$$
\text { Penelitian ini menggunakan }
$$

Rancangan Acak Lengkap Faktorial dengan 3 ulangan. Faktor I : jumlah bibit (B), terdiri atas 3 taraf $B_{1}=1$ bibit per rumpun, $\mathrm{B}_{2}=2$ bibit per rumpun, $\mathrm{B}_{3}=3$ bibit per rumpun. Faktor II : populasi tanaman berdasarkan sistem tanam jajar legowo yang dimodifikasi (L) terdiri atas 5 taraf :
$\mathrm{L}_{0}=$ sistem tanam konvensional dengan dengan jarak tanam $30 \mathrm{~cm} \times 30 \mathrm{~cm}$ populasi 35 rumpun/plot, $\mathrm{L}_{1}=$ jajar legowo dengan jarak tanam $20 \mathrm{~cm} \times 20 \mathrm{~cm}$ populasi 60 rumpun/plot, $\mathrm{L}_{2}=$ jajar legowo dengan jarak tanam $10 \mathrm{~cm}$ x $20 \mathrm{~cm}$ populasi 114 rumpun/plot, $\mathrm{L}_{3}=$ jajar legowo dengan jarak tanam $10 \mathrm{~cm} \times 20 \mathrm{~cm}$ dan disisipi tanaman setiap $10 \mathrm{~cm}$ populasi 154 rumpun/plot), $\mathrm{L}_{4}=$ jajar legowo dengan jarak tanam $10 \mathrm{~cm} \times 10 \mathrm{~cm}$ populasi 190 rumpun/plot. Luas lahan yang digunakan sebesar 15915,2cm, dengan total plot sebanyak 45 plot, masing-masing plot berukuran $2 \mathrm{~cm} \times 1,5 \mathrm{~cm}$.

\section{HASIL DAN PEMBAHASAN}

\section{Tinggi Tanaman (cm)}

Pada Tabel 1 dapat dilihat bahwa kombinasi perlakuan terbaik untuk tinggi tanaman terdapat pada perlakuan $\mathrm{B}_{2} \mathrm{~L}_{4}(2$ bibit dengan sistem tanam jajar legowo dengan populasi 190 rumpun/ plot) yaitu sebesar $34,31 \mathrm{~cm}$ sedangkan rataan tinggi tanaman terendah terdapat pada perlakuan $\mathrm{B}_{1} \mathrm{~L}_{3}$ (1 bibit dengan populasi 154 rumpun per plot) yaitu sebesar $29,37 \mathrm{~cm}$. Interaksi antara jumlah bibit dan populasi tanaman hanya terlihat berpengaruh nyata pada umur 2 MST. Hal ini menunjukkan bahwa semakin banyak populasi tanaman maka pertumbuhan tinggi tanaman lebih tinggi, karena masih tercukupinya hara di awal pertumbuhan sehingga belum ada persaingan yang tinggi. Danggulo et al. (2017) menyatakan bahwa tinggi tanaman tertinggi dihasilkan pada populasi tanaman yang lebih banyak dalam satu hamparan.

Pada umur 4 MST hingga 8 MST perlakuan jumlah bibit, populasi tanaman, dan interaksi tanaman tidak berpengaruh nyata terhadap tinggi tanaman karena kebutuhan unsur hara sudah dipenuhi pada awal pertumbuhan dan pemberian pupuk pada setiap perlakuan diberikan berimbang. Satria (2016) menyatakan bahwa pemberian pupuk secara berimbang akan menghasilkan pertumbuhan yang seragam dengan perlakuan yang berbeda. 
Tabel 1. Pengaruh Interaksi Jumlah Bibit dan Populasi Tanaman Terhadap Tinggi Tanaman (cm) pada Semua Umur Pengamatan.

\begin{tabular}{ccccc}
\hline \multirow{2}{*}{ Perlakuan } & \multicolumn{4}{c}{ Pengamatan } \\
\cline { 2 - 5 } & 2 MST & 4 MST & 6 MST & 8 MST \\
\hline $\mathrm{B}_{1} \mathrm{~L}_{0}$ & $30.33 \mathbf{b c}$ & 52.75 & 74.46 & 93.01 \\
$\mathrm{~B}_{1} \mathrm{~L}_{1}$ & $33.78 \mathbf{a b}$ & 56.86 & 79.11 & 96.58 \\
$\mathrm{~B}_{1} \mathrm{~L}_{2}$ & $29.73 \mathbf{c}$ & 57.06 & 78.99 & 95.38 \\
$\mathrm{~B}_{1} \mathrm{~L}_{3}$ & $29.37 \mathbf{c}$ & 56.41 & 79.42 & 94.62 \\
$\mathrm{~B}_{1} \mathrm{~L}_{4}$ & $30.99 \mathbf{a b c}$ & 55.39 & 77.63 & 90.63 \\
$\mathrm{~B}_{2} \mathrm{~L}_{0}$ & $29.53 \mathbf{c}$ & 55.08 & 77.78 & 92.11 \\
$\mathrm{~B}_{2} \mathrm{~L}_{1}$ & $29.81 \mathbf{c}$ & 57.05 & 78.60 & 94.90 \\
$\mathrm{~B}_{2} \mathrm{~L}_{2}$ & $32.49 \mathbf{a b c}$ & 60.01 & 80.57 & 95.35 \\
$\mathrm{~B}_{2} \mathrm{~L}_{3}$ & $33.14 \mathbf{a b c}$ & 61.29 & 81.93 & 96.68 \\
$\mathrm{~B}_{2} \mathrm{~L}_{4}$ & $34.31 \mathbf{a}$ & 62.23 & 79.37 & 96.58 \\
$\mathrm{~B}_{3} \mathrm{~L}_{0}$ & $32.99 \mathbf{a b c}$ & 58.92 & 84.07 & 97.75 \\
$\mathrm{~B}_{3} \mathrm{~L}_{1}$ & $29.41 \mathbf{c}$ & 59.14 & 79.41 & 95.13 \\
$\mathrm{~B}_{3} \mathrm{~L}_{2}$ & $31.51 \mathbf{a b c}$ & 58.29 & 80.37 & 97.72 \\
$\mathrm{~B}_{3} \mathrm{~L}_{3}$ & $31.25 \mathbf{a b c}$ & 61.04 & 82.11 & 98.67 \\
$\mathrm{~B}_{3} \mathrm{~L}_{4}$ & $31.00 \mathbf{a b c}$ & 61.90 & 80.93 & 94.64 \\
\hline
\end{tabular}

Keterangan : Angka yang diikuti oleh huruf yang berbeda pada kolom yang sama adalah berbeda nyata berdasarkan Uji Jarak Berganda Duncan pada taraf 5\%

\section{Jumlah Anakan (batang)}

Berdasarkan dari hasil analisis ditunjukkan bahwa jumlah bibit berpengaruh nyata terhadap jumlah anakan pada umur 2 MST. Rataan jumlah anakan tertinggi yaitu pada $\mathrm{B}_{3} \quad$ (3 bibit per rumpun) sebesar 6,04 batang, sedangkan rataan terendah yaitu pada $\mathrm{B}_{1}$ (1 bibit per rumpun) sebesar 3,36 batang. Pada umur 4 MST hingga 8 MST jumlah bibit tidak memberikan pengaruh yang nyata terhadap jumlah anakan. Hal ini dikarenakan pada awalnya jumlah 1 bibit per rumpun menunjukkan pertumbuhan yang lambat. Tetapi pada minggu berikutnya, perlakuan 1 bibit per rumpun sudah mulai berkembang cepat, bahkan hasil anakannya hampir sama banyaknya dan melampaui hasil jumlah anakan pada perlakuan 2 dan 3 bibit per rumpun. Ali et.al. (2017) menyatakan bahwa pada minggu-minggu selanjutnya pemakaian bibit 2 atau 3 per lubang tanam sudah mulai terjadi persaingan antar tanaman, sedangkan 1 bibit per lubang tanam persaingan ini dapat dikurangi, sehingga perkembangan anakan tetap berjalan dengan baik.
Populasi tanaman berpengaruh nyata terhadap jumlah anakan pada umur 2 MST hingga 8 MST. Rataan jumlah anakan tertinggi yaitu pada $\mathrm{L}_{0}$ (populasi 35 rumpun/plot) sebesar 39,73 batang, sedangkan rataan terendah pada $\mathrm{L}_{4}$ (populasi 190 rumpun per plot) yaitu sebesar 20,31 batang. Populasi tanaman yang semakin banyak memiliki jarak tanam yang semakin rapat sehingga terjadi persaingan yang tinggi antar tanaman, maka pertumbuhan jumlah anakan melambat, sementara jika jarak tanam semakin lebar maka pertumbuhan tanaman akan meningkat karena adanya peningkatan penangkapan radiasi oleh tanaman. Ikhwani et al. (2013) menyatakan bahwa jarak tanam yang lebar akan meningkatkan penangkapan radiasi surya oleh tajuk tanaman, sehingga meningkatkan pertumbuhan tanaman seperti jumlah anakan produktif, volume dan panjang akar total, meningkatkan bobot kering tanaman, dan bobot gabah per rumpun. 
Tabel 2. Pengaruh Jumlah Bibit dan Populasi Tanaman terhadap Rata - Rata Jumlah Anakan (batang) per lubang tanam Sampel Tanaman Padi Sawah

\begin{tabular}{|c|c|c|c|c|c|c|c|}
\hline \multirow{2}{*}{$\begin{array}{c}\text { Umur } \\
\text { Pengamatan }\end{array}$} & \multirow{2}{*}{$\begin{array}{c}\text { Jumlah } \\
\text { Bibit }\end{array}$} & \multicolumn{5}{|c|}{ Populasi Tanaman } & \multirow{2}{*}{ Rataan } \\
\hline & & $\mathrm{L}_{0}$ & $\mathrm{~L}_{1}$ & $\mathrm{~L}_{2}$ & $\mathrm{~L}_{3}$ & $\mathrm{~L}_{4}$ & \\
\hline \multirow{4}{*}{$2 \mathrm{MST}$} & $\mathrm{B}_{1}$ & 3.6 & 3.3 & 3.8 & 3.0 & 3.1 & $3.36 \mathrm{c}$ \\
\hline & $\mathrm{B}_{2}$ & 4.7 & 5.3 & 5.7 & 4.3 & 5.2 & $5.04 \mathrm{~b}$ \\
\hline & $\mathrm{B}_{3}$ & 6.5 & 6.2 & 6.1 & 6.1 & 5.3 & $6.04 \mathbf{a}$ \\
\hline & Rataan & $4.91 \mathbf{b c}$ & $4.93 \mathbf{b}$ & $5.20 \mathbf{a}$ & $4.49 \mathrm{~d}$ & $4.53 \mathrm{~d}$ & \\
\hline \multirow{4}{*}{$4 \mathrm{MST}$} & $\mathrm{B}_{1}$ & 31.20 & 26.33 & 22.47 & 16.60 & 14.07 & 22.13 \\
\hline & $\mathrm{B}_{2}$ & 31.33 & 27.33 & 22.53 & 22.00 & 19.33 & 24.51 \\
\hline & $\mathrm{B}_{3}$ & 32.20 & 25.67 & 25.93 & 23.80 & 18.20 & 25.16 \\
\hline & Rataan & $31.58 \mathbf{a}$ & $26.44 \mathrm{~b}$ & $23.64 \mathrm{c}$ & $20.80 d$ & $17.20 \mathbf{e}$ & \\
\hline \multirow{4}{*}{$6 \mathrm{MST}$} & $\mathrm{B}_{1}$ & 40.20 & 34.07 & 24.53 & 21.80 & 20.53 & 28.23 \\
\hline & $\mathrm{B}_{2}$ & 36.73 & 32.00 & 25.53 & 24.20 & 22.67 & 28.23 \\
\hline & $\mathrm{B}_{3}$ & 37.20 & 31.27 & 32.07 & 28.13 & 21.27 & 29.99 \\
\hline & Rataan & $38.04 \mathbf{a}$ & $32.45 \mathbf{b}$ & $27.38 \mathbf{c}$ & $24.71 \mathrm{~d}$ & $21.49 \mathrm{e}$ & \\
\hline \multirow{4}{*}{$8 \mathrm{MST}$} & $\mathrm{B}_{1}$ & 42.13 & 34.80 & 25.00 & 20.93 & 20.40 & 28.65 \\
\hline & $\mathrm{B}_{2}$ & 37.93 & 32.20 & 23.13 & 20.73 & 20.87 & 26.97 \\
\hline & $\mathrm{B}_{3}$ & 39.13 & 32.40 & 31.87 & 27.60 & 19.67 & 30.13 \\
\hline & Rataan & $39.73 \mathbf{a}$ & $33.13 \mathbf{b}$ & $26.67 \mathrm{c}$ & $23.09 d$ & $20.31 \mathrm{e}$ & \\
\hline
\end{tabular}

Keterangan : $\quad$ Angka yang diikuti oleh huruf yang berbeda pada kolom yang sama adalah berbeda nyata berdasarkan Uji Jarak Berganda Duncan pada taraf 5\%

Panjang Malai (cm), Jumlah Malai (malai), Bobot Gabah Bruto(g), Bobot Gabah Netto (g), Bobot 1000 Gabah (g), Bobot Jerami Kering (g)

Hasil uji beda rataan pengaruh jumlah bibit dan populasi tanaman terhadap jumlah malai (malai), bobot gabah bruto (g), bobot gabah netto $(\mathrm{g})$, bobot gabah hampa $(\mathrm{g})$, bobot gabah 1000 butir $(\mathrm{g})$, bobot jerami kering $(\mathrm{g})$ disajikan pada Tabel 3.

Pada Tabel 3 menunjukkan faktor jumlah bibit dan populasi tanaman tidak berpengaruh nyata terhadap panjang malai pada umur 2 MST hingga 8 MST. Hal ini dikarenakan populasi tanaman dan jumlah bibit yang banyak, sehingga daun tanaman akan tumpang tindih yang mengakibatkan terbatasnya pengambilan radiasi surya. Satria (2016) menyatakan bahwa jarak tanam yang rapat akan meningkatkan penangkapan radiasi surya oleh tajuk tanaman, sehingga meningkatkan pertumbuhan tanaman seperti jumlah anakan produktif, volume dan panjang akar total, meningkatkan bobot kering tanaman dan bobot gabah per rumpun, tetapi tidak berpengaruh terhadap hasil per satuan luas.

Tabel 3 menunjukkan bahwa faktor populasi tanaman berpengaruh nyata terhadap jumlah malai. Hasil tertinggi terdapat pada perlakuan $\mathrm{L}_{0}$ (sistem tanam jajar legowo dengan populasi 35 rumpun per plot) dan terendah pada perlakuan $\mathrm{L}_{3}$ (sistem tanam jajar legowo dengan populasi 154 rumpun per plot). Hal ini menunjukkan bahwa jarak tanam yang rapat akan menghasilkan jumlah malai yang sedikit karena persaingan radiasi surya dan unsur hara yang cukup tinggi. Satria (2016) menyatakan bahwa penerapan beberapa jarak tanam dan sistem tanam berpengaruh sangat nyata terhadap jumlah malai per plot tanaman padi. Hal ini dipengaruhi oleh faktor lingkungan.

Tabel 3 memperlihatkan bahwa faktor jumlah bibit berpengaruh nyata terhadap bobot gabah bruto per plot. Dimana hasil tertinggi yaitu pada perlakuan $\mathrm{B}_{1}$ ( 1 bibit per rumpun) sebesar 2695,27g, jika dikonversi ke ton/ha maka akan mencapai 9 ton/ha, sedangkan hasil terendah yaitu pada perlakuan $\mathrm{B}_{3}$ (3 bibit per rumpun) sebesar 
2183,33g, jika dikonversikan ke ton/hektar akan mencapai 7,27 ton/ha. Hal ini dikarenakan pada akhir masa vegetatif jumlah anakan pada perlakuan 1 bibit mengalami peningkatan bahkan sama dan hampir melebihi jumlah anakan 2 dan 3 bibit per rumpun, sehingga pada perlakuan 1 bibit menghasilkan jumlah malai yang lebih tinggi untuk menghasilkan gabah yang banyak pula. Tambunan (2017) menyatakan bahwa penggunaan 2 atau 3 bibit memang tidak memerlukan penyulaman bila terjadi kematian satu tanaman sehingga jumlah anakan dan malai yang dihasilkan banyak. Namun, seiring dengan perkembangannya, produktivitas individu akan menjadi rendah.

Pada faktor perlakuan populasi tanaman, diperoleh hasil gabah bruto tertinggi pada perlakuan $\mathrm{L}_{1}$ (sistem tanam jajar legowo dengan populasi 60 rumpun per plot) yaitu sebesar 2624,78 g, jika dikonversikan ke ton/hektar maka mencapai 8,74 ton/ha, sedangkan hasil terendah yaitu terdapat pada perlakuan $\mathrm{L}_{4}$ (sistem tanam jajar legowo dengan populasi 190 rumpun per plot) sebesar $2177 \mathrm{~g}$, jika di konversikan ke ton/ha maka mencapai 7,25 ton/ha. Hal ini menunjukkan bahwa ketepatan pemilihan sistem tanam akan menghasilkan produksi gabah yang tinggi. Hal ini sesuai dengan literatur Tambunan (2017) yang menyatakan bahwa keunggulan sistem tanam jajar legowo adalah meskipun populasi tanaman per satuan luas banyak, tetapi karena adanya ruang kosong antara setiap 2 atau 4 baris tanaman sehingga dapat memberi ruang sirkulasi udara, pemasukan cahaya dan juga aliran air dan penyebaran unsur hara yang lebih merata sehingga tampilan pertumbuhan dan komponen hasil yang dihasilkan tinggi juga akan semakin lebih baik sesuai dengan urutan kerapatan legowo yang dilakukan.

Tabel 3 menunjukkan faktor jumlah bibit berpengaruh nyata terhadap bobot gabah netto per plot. Hasil tertinggi terdapat pada perlakuan $\mathrm{B}_{1}$ (1 bibit per rumpun) sebesar $2515,20 \mathrm{~g}$, jika dikonversikan ke ton/hektar akan mencapai 8,38 ton/ha, sedangkan hasil terendah terdapat pada perlakuan $\mathrm{B}_{3}$ (3 bibit per rumpun) sebesar 2010,86g, jika dikonversikan ke ton/hektar maka akan mencapai 6,7 ton/ha. Hal ini dikarenakan persaingan perebutan radiasi surya dan unsur hara pada perlakuan 1 bibit lebih rendah dibandingkan dengan perlakuan 2 dan 3 bibit per rumpun, sehingga hasil produksinya lebih tinggi. Tambunan (2017) menyatakan bahwa tingginya bobot gabah netto pada penggunaan 1 bibit per rumpun disebabkan rendahnya kompetisi antar tanaman padi dalam mendapatkan unsur hara dan cahaya, sehingga tanaman dapat tumbuh lebih baik dan memberikan keragaman komponen hasil yang baik. Sebaliknya, kompetisi antar tanaman padi pada perlakuan 2 dan 3 bibit per rumpun sudah lebih tinggi, sehingga berpengaruh pada penurunan produksi.

Pada faktor perlakuan populasi tanaman juga menunjukkan pengaruh yang nyata. Dimana hasil tertinggi terdapat pada perlakuan $\mathrm{L}_{1}$ (sistem tanam jajar legowo dengan populasi 60 rumpun per plot) sebesar 2497,44g, jika dikonversikan ke ton/hektar akan mencapai 8,32 ton/ha, sedangkan hasil terendah terdapat pada perlakuan $\mathrm{L}_{4}$ (sistem tanam jajar legowo dengan populasi 190 rumpun per plot) sebesar 1993,67g, jika di konversikan ke ton/hektar maka mencapai 6,64 ton/ha. Hal ini menunjukkan bahwa ketepatan pemilihan sistem tanam akan menghasilkan produksi gabah yang tinggi. Ikhwani et al. (2013) menyatakan bahwa Pada prinsipnya sistem tanam jajar legowo adalah meningkatkan populasi dengan cara mengatur jarak tanam. Sistem tanam ini juga memanipulasi tata letak tanaman, sehingga rumpun tanaman sebagian besar menjadi tanaman pinggir. Tanaman padi yang berada di pinggir akan mendapatkan sinar matahari yang lebih banyak, sehingga menghasilkan gabah lebih tinggi dengan kualitas yang lebih baik.

Pada Tabel 3 dapat dilihat bahwa faktor perlakuan jumlah bibit berpengaruh nyata terhadap bobot 1000 gabah kering. Dari data dapat diketahui bahwa bobot 1000 gabah tertinggi terdapat pada perlakuan $\mathrm{B}_{2}$ (2 bibit per rumpun) yaitu sebesar $27,77 \mathrm{~g}$. Sedangkan bobot 1000 gabah terendah terdapat pada perlakuan $\mathrm{B}_{1} \quad(1$ bibit per rumpun). 
Tabel 3. Pengaruh Jumlah Bibit dan Populasi Tanaman terhadap Panjang Malai (cm), Jumlah Malai (malai), Bobot Gabah Bruto (g), Bobot Gabah Netto (g), Bobot 1000 Gabah (g), Bobot Jerami Kering (g)

Perlakuan

$\begin{array}{ccc}\text { Panjang } & \text { Jumlah } & \text { Bobot } \\ \text { Malai } & \text { Malai } & \text { Gabah } \\ (\mathbf{c m}) & \text { (malai) } & \text { Bruto }(\mathrm{g})\end{array}$

\section{Parameter}

\begin{tabular}{ccc} 
Bobot & Bobot & Bobot \\
Gabah Netto & Gabah & Jerami \\
$($ g) & 1000 Butir & Kering $(\mathrm{g})$ \\
& $(\mathrm{g})$ & \\
\hline
\end{tabular}

\section{Jumlah Bibit}

$\begin{array}{lllllll}\text { (B) } & & & & & & \\ \mathrm{B}_{1} & 36,91 & 18.35 & 2695.27 \mathbf{a} & 2515.20 \mathbf{a} & 26.46 \mathbf{c} & 2057.67 \\ \mathrm{~B}_{2} & 36.60 & 18.56 & 2506.46 \mathbf{b} & 2361.33 \mathbf{b} & 27.77 \mathbf{a} & 1973.93 \\ \mathrm{~B}_{3} & 36.96 & 21.32 & 2183.33 \mathbf{c} & 2010.86 \mathbf{c} & 27.13 \mathbf{b} & 1912.67\end{array}$

\section{Populasi \\ $\operatorname{Tanaman}(\mathbf{L})$}

$\begin{array}{lcccccc}\mathrm{L}_{0} & 37.82 & 24.96 \mathbf{a} & 2580.55 \mathbf{a b} & 2431.89 \mathbf{a b} & 27.62 & 2075.55 \\ \mathrm{~L}_{1} & 39.07 & 21,49 \mathbf{b} & 2624.78 \mathbf{a} & 2497.44 \mathbf{a} & 26.82 & 2122.22 \\ \mathrm{~L}_{2} & 37.98 & 20.36 \mathbf{b c} & 2542.67 \mathbf{a b c} & 2354.22 \mathbf{a b c} & 27.02 & 1938.22 \\ \mathrm{~L}_{3} & 36.28 & 14.33 \mathbf{d} & 2383.44 \mathbf{d} & 2201.78 \mathbf{d} & 26.94 & 1905.56 \\ \mathrm{~L}_{4} & 32.95 & 15.91 \mathbf{d} & 2177.00 \mathbf{e} & 1993.67 \mathbf{e} & 27.19 & 1865.55\end{array}$

Keterangan : Angka yang diikuti oleh huruf yang berbeda pada kolom yang sama adalah berbeda nyata berdasarkan Uji Jarak Berganda Duncan pada taraf $5 \%$

\section{bobot}

sebesar 26,46g. Dari hasil analisis

1000 gabah kering, pada perlakuan 2 bibit per lubang tanam menunjukkan bahwa jumlah bibit 2 merupakan jumlah bibit yang optimal untuk meningkatkan bobot 1000 gabah kering. Perbedaan berat bobot gabah ini dipengaruhi beberapa faktor seperti faktor genetik, dan banyaknya bahan kering yang terkandung. Susilo et al. (2015) menyatakan bahwa tinggi rendahnya berat biji tergantung banyak bahan kering yang terkandung, bahan kering biji diperoleh dari hasil fotosintesis yang selanjutnya dapat digunakan untuk pengisian biji. Tanaman yang ditanam dengan jumlah bibit per lubang tanam tidak dipengaruhi oleh faktor lingkungan dalam pengisian gabah dan berat 1000 biji gabah tetapi lebih dipengaruhi oleh faktor genetik tanaman itu sendiri.

Berdasarkan penelitian yang telah dilaksanakan, diketahui bahwa faktor perlakuan jumlah bibit dan populasi tanaman tidak berpengaruh nyata terhadap bobot jerami kering. Hal ini diduga, bahwa populasi tanaman dan jumlah bibit yang sedikit pada akhir masa vegetatif dapat menghasilkan jumlah anakan yang hampir sama banyaknyadengan populasi tanaman dan jumlah bibit yang banyak, sehingga daun tanaman akan tumpang tindih yang mengakibatkan terbatasnya pengambilan radiasi surya. Satria (2016) menyatakan bahwa jarak tanam yang rapat akan meningkatkan penangkapan radiasi surya oleh tajuk tanaman, sehingga meningkatkan pertumbuhan tanaman seperti jumlah anakan bobot gabah per rumpun, tetapi tidak berpengaruh terhadap hasil per satuan luas.

Produksi padi per hektar yang dicapai dalam penelitian ini adalah sebesar 9,46 ton/ha. Hasil ini memang belum dapat mencapai target produksi yang telah ditentukan yakni 10 ton/ha, karena adanya karena adanya serangan penggerek batang padi putih (Tryporhyza innotata) yang menyerang tanaman padi pada saat berbunga. Serangan ini ditandai dengan warna daun 
menguning, ujung daun menggulung, di dalam gulungan daun dan batang terdapat penggerek. Hal ini mengakibatkan hasil gabah menjadi tidak sempurna. Badan Ketahanan Pangan dan Penyuluhan Pertanian Aceh (2009) menyatakan bahwa stadia tanaman yang rentan terhadap serangan

\section{SIMPULAN}

Penggunaan 1 bibit per rumpun yang nyata meningkatkan produksi gabah bruto, gabah netto tanaman padi sawah (Oryza sativa L.). Produksi padi tertinggi dihasilkan pada sistem tanam jajar legowo dengan jarak tanam $20 \mathrm{~cm}$ x $20 \mathrm{~cm}$ populasi tanaman 60 rumpun per plot. Interaksi antara jumlah bibit per lubang tanam dan populasi tanaman secara nyata meningkatkan pertumbuhan tinggi tanaman tetapi tidak nyata meningkatkan produksi tanaman padi sawah (Oryza sativa L.).

\section{DAFTAR PUSTAKA}

Ali, M., A. Hosir., dan Nurlina. 2017. Perbedaan Jumlah Bibit per Lubang Tanam Terhadap Pertumbuhan dan Hasil Tanaman Padi (Oryza sativa L.) dengan Menggunakan Metode The System Rice Intensification. Gontor Agrotech Science Journal Vol. 3 No. 1

Badan Ketahanan Pangan dan Penyuluh Pertanian Aceh. 2009. Budidaya Tanaman Padi. Balai Pengkajian Teknologi dan Pertanian, Nanggroe Aceh Darussalam.

BPS. 2016. Produksi Padi dan Palawija Sumatera Utara (Angka Sementara Tahun 2014). [Online]. www.bps.go.id. Diakses pada 20 Februari 2017.

Bobihue, J. 2013. Sistem Tanam Padi Jajar Legowo. Balai Pengkajian Teknologi Pertanian Jambi, Jambi.

Burbey, S. Abdullah, dan Nieldalina. 2014. Pengaruh Umur Dan Jumlah Bibit Padi Sawah Varietas Umur Genjah (Vusgh) Dan Varietas Umur sangat Genjah di Sitiung, Solok. Balai penggerek batang adalah dari pembibitan sampai pembentukan malai. Gejala kerusakan yang ditimbulkannya mengakibatkan anakan coati yang disebut sundep pada tanaman stadia vegetatif, dan beluk (malai hampa) pada tanaman stadia generatif.

Pengkajian Teknologi Pertanian Sumatera Barat, Padang.

Danggulo, C. V., I. M. Lapanjang, U. Made. 2017.Pertumbuhan dan Hasil Tanaman Padi (Oryza sativa L.) Pada Berbagai Pola Jajar Legowo dan Jarak Tanam. J. Agroland 24 (1) : 27-35.

Ikhwani, G. R. Pratiwi, E. Paturrohman, dan A. K. Makarim. 2013. Peningkatan Produktivitas Melalui Penerapan Jarak Tanam Jajar Legowo. IPTEK Tanaman Pangan Vol.8 No.2.

Karokaro, S., J. E. Rogi, D. S. Runtunuwu, dan P. Tumewu. 2014. Pengaturan Jarak Tanam Padi Sawah (Oryza sativa L.) Pada Sistem Tanam Jajar Legowo.[Online].www.portalgaruda.c om. Diakses pada 23 Januari 2017.

Nasution, H. E. 2014. Pengaruh Pemberian Pupuk N, P, K, dan Mg Berdasarkan Unsur Hara Tanah yang Diserap untuk Meningkatkan Produksi Padi Sawah (Oryza sativa). Fakultas Pertanian Universitas Graha Nusantara, Padangsidimpuan.

Satria, B. 2016. Peningkatan Produktivitas Padi Sawah (Oryza sativa L.) Melalui Penerapan Beberapa Jarak Tanam dan Sistem Tanam. Diakses dari http://www.repository.usu.ac.id pada tanggal 05 Maret 2017.

Suswandi dan S. Imam. 2011. Manual. Pembelajaran Penerapan SRI (System of Rice Intensification) di Lahan Tadah Hujan, Kabupaten Boyolali, LSK Bina Bakat, Surakarta.

Susilo, J., Ardian, dan E. Ariani. 2015. Pengaruh Jumlah Bibit per Lubang Tanam dan Dosis Pupuk N, P, dan K Terhadap Pertumbuhan dan Produksi Padi Sawah (Oryza sativa L.) dengan Metode SRI. Jom Faperta Vol. 2 No. 1 
Tambunan, S. 2017. Pengaruh Jumlah Bibit dan Sistem Tanam Jajar Legowo yang Dimodifikasi Terhadap Pertumbuhan dan Produksi Padi Sawah (Oryza sativa L.) di Kecamatan Medan Tuntungan. [Online]. www.repository.usu.ac.id. Diakses pada 30 Oktober 2017 